\title{
FORMULASI SEDIAAN GEL EKSTRAK ETANOL DAUN SENDUDUK (Melastoma malabathricum L.) TERHADAP UJI KESTABILAN FISIK DAN UJI AKTIVITAS ANTIBAKTERI PADA STAPHYLOCOCCUS AUREUS
}

\section{FORMULATION OF ETHANOL LEAF SEED EXTRACT GEL (Melastoma malabathricum L.) ON PHYSICAL STABILITY TEST AND ANTIBACTERIAL ACTIVITY TEST ON STAPHYLOCOCCUS AUREUS}

\author{
Dewi Marlina*1, Minda Warnis ${ }^{2}$, Muhamad Taswin ${ }^{3}$ \\ 1,2,3 Jurusan Farmasi Poltekkes Kemenkes Palembang, Sumatera Selatan, Indonesia \\ (email penulis koresponden: dewimarlina@poltekkespalembang.ac.id)
}

Info Artikel: Diterima: 11 September 2020 Revisi: 31 Oktober 2020 Disetujui: 20 Desember 2020

\begin{abstract}
ABSTRAK
Latar Belakang: Produk gel dari ekstrak etanol daun senduduk sebagai antibakteri di pasaran belum banyak ditemukan, karena itu dilakukan penelitian dengan menggunakan ekstrak etanol daun senduduk, yang diformulasikan dalam sediaan gel, menggunakan basis gel HPMC, dengan sasaran penggunaan secara topikal. Tujuan Penelitian ini untuk mengetahui ekstrak etanol daun senduduk (Melastoma malabathricum L.) dapat diformulasikan dalam bentuk sediaan gel yang stabil secara fisik dan mempunyai aktivitas antibakteri dengan memformulasikan sediaan Gel Ekstrak Etanol Daun Senduduk (Melastoma malabathricum L.).

Metode: Penelitian ini menggunakan Metode eksperimental dengan membuat 3 jenis formula gel yang mengandung ekstrak etanol daun senduduk (Melastoma malabathricum L.) $4 \%$ dengan memvariasikan HPMC sebagai gelling agent pada konsentrasi 3\%, 3,5\% dan 4\%. Uji aktivitas antibakteri dilakukan dengan metode difusi agar terhadap bakteri Staphylococcus aureus. Sediaan disimpan selama 28 hari dan dievaluasi $\mathrm{pH}$, viskositas, homogenitas, intensitas warna dan bau serta iritasi kulit pada hari ke-0, ke-7, ke-14, ke-21 dan ke-28.

Hasil: Semakin tinggi konsentrasi HPMC (gelling agent) maka semakin tinggi viskositas dan semakin rendah daya sebar dan $\mathrm{pH}$, namun tidak berpengaruh terhadap homogenitas, warna, bau dan iritasi kulit. Hasil uji antibakteri menunjukkan bahwa pada formula ekstrak I zona hambat berkisar $11-16,5 \mathrm{~mm}$, formula II zona hambat berkisar $10-16 \mathrm{~mm}$ dan pada formula III zona hambat berkisar $10-14,5 \mathrm{~mm}$. Uji statistik oneway anova $(\mathrm{p}<0,05)$ untuk membandingkan zona hambatan pada sediaan pada hari ke-0, ke-7, ke-14, ke-21 dan ke-28, didapatkan signifikasi 0,412(p>0.05).

Kesimpulan: Sediaan gel yang mengandung Ekstrak etanol daun senduduk pada Formula I mempunyai kestabilan fisik yang memenuhi persyaratan untuk dibuat sediaan gel.

Kata Kunci:Daun Senduduk, Gel, Antibakteri, Staphylococcus aureus
\end{abstract}




\begin{abstract}
Background: Gel products from ethanol extract of senduduk leaves as antibacterial on the market have not been widely found, therefore research was carried out using ethanol extract of senduduk leaves, which is formulated in a gel preparation, using HPMC gel base, with the target of topical use. The purpose of this study was to determine the ethanol extract of senduduk leaves (Melastoma malabathricum L.) can be formulated into a gel dosage form that is physically stable and has antibacterial activity by formulating Senduduk Leaf Ethanol Extract Gel (Melastoma malabathricum L.).

Method: This study used an experimental method by making 3 types of gel formulas containing 4\% ethanol extract of senduduk leaves (Melastoma malabathricum L.) by varying HPMC as a gelling agent at a concentration of 3\%, 3.5\% and 4\%. Antibacterial activity test was carried out by agar diffusion method against Staphylococcus aureus bacteria. The preparations were stored for 28 days and evaluated for $\mathrm{pH}$, viscosity, homogeneity, color and odor intensity and skin irritation on days 0 , $7^{\text {th }}, 14^{\text {th }}, 21^{\text {st }}$, and $28^{\text {th }}$.

Results: This study showed that the higher concentration of HPMC (gelling agent), The higher the concentration of HPMC (gelling agent), The higher the viscosity and the lower the spread ability and $\mathrm{pH}$, but did not affect the homogeneity, color, odor and skin irritation. Antibacterial test results showed that in formula I inhibition zone extracts ranged from 11-16.5 mm, formula II inhibition zone ranged from 10- $16 \mathrm{~mm}$ and in formula III inhibition zone ranged from 10 to $14.5 \mathrm{~mm}$. From One-way ANOVA statistical test $(p<0.05)$ to compare inhibition zones on preparations on day $0,7^{\text {th }}$, $14^{\text {th }}, 21^{\text {st }}$, and $28^{\text {th }}$ was obtained significance of 0.412 ( $\left.p>0.05\right)$.
\end{abstract}

Conclusion: Gel preparations containing ethanol extract of Melastoma malabathricum L.leavesin Formula I have physical stability that meets the requirements for making gel preparations.

Keywords:Melastoma malabathricum L. Leaves, Gel. Antibacteria, Staphylococcus aureus

\title{
PENDAHULUAN
}

Penyakit infeksi merupakan salah satu masalah kesehatan terbesar yang terjadi tidak hanya di Indonesia, tetapi juga di seluruh dunia. Penyakit infeksi ini merupakan penyebab utama kematian. Penyakit infeksi tidak hanya disebabkan oleh virus tetapi juga bakteri. ${ }^{1}$ Beberapa bakteri yang dapat menyebabkan penyakit diantaranya adalah Staphylococcus aureus (S. aureus) dan Escherichia coli ${ }^{2}$. Menurut Dinkes Kota Palembang 2012, ${ }^{3}$ prevalensi penderita penyakit infeksikulit di Palembang sebesar 5,98\% yang penderitanya mulai dari balita hingga dewasa. Bisul merupakan salah satu penyakit infeksi kulit akibat bakteri dan merupakan penyakit yang ringan namun sangat mengganggu. Staphylococcus aureus menyebabkan gangguan kulit akibat infeksi pada kantung rambut kulit. ${ }^{4}$

Salah satu tanaman yang berasal dari indonesia yang berpotensi sebagai tanaman obat adalah daun senduduk (Melastoma malabathricum L.). Daun merupakan bagian dari tanaman senduduk yang sering digunakan sebagai obat. Secara empiris daun senduduk dapat mengobati penyakit disentri, diare, bisul, luka luar dan sariawan. Daun senduduk digunakan untuk pengobatan bisul dan luka luar dengan cara di tumbuk sampai halus kemudian hasil tumbukan di tempelkan pada bagian bisul atau luka luar ${ }^{5}$.

Berdasarkan penelitian Simanjunta ${ }^{6}$, dan Kusumowati dkk ${ }^{7}$, flavonoid, saponin dan tanin merupakan kandungan dari daun senduduk. Aktivitas antibakteri dari senyawa golongan tanin mempunyai sifat sebagai pengelat berefek spasmolitik, yang menganggu pertumbuhan sel dengan cara mengerutkan membran sel. Karena terganggunya pertumbuhan sel, maka pertumbuhan sel terhambat karena sel tidak dapat melakukan aktivitas hidupnya dan bahkan mati. Reaksi dengan membran sel, inaktivasi fungsi materi genetik merupakan efek bakteri dari tannin ${ }^{8}$.

Sediaan farmasi yang aman, nyaman dan mudah digunakan perlu dikembangkan. Untuk meningkatkan efektivitas penggunaan daun senduduk dengan dibuat sediaan topical. yang paling disukai adalah gel, karena memiliki

kandungan air yang bersifat menyejukkan, melembabkan, mudah digunakan ${ }^{9}$, dan tidak 
memberikan kesan lengket di kulit ${ }^{10}$. Pemilihan gelling agent dalam memformulasi sediaan harus diperhatikan untuk memperoleh sediaan gel yang baik.

Hasil penelitian Madan and Singh ${ }^{11}$, basis HPMC memiliki daya sebar yang luas dan kecepatan pelepasan obat yang baik. HPMC sebagai basis gel merupakan gelling agent yang sering digunakan dalam produksi kosmetik dan obat, karena dapat menghasilkan gel yang bening, mudah larut dalam air, dan mempunyai ketoksikan yang rendah. Selain itu HPMC bersifat netral, mempunyai $\mathrm{pH}$ yang stabil antara 3-11, tahan terhadap panas, serangan mikroba, dan asam basa 12,13, Telah dibuktikan dalam penelitian Arikumalasari, Dewantara dan Wijayanti ${ }^{14}$, bahwa penggunaan HPMC sebagai gelling agent dengan konsentrasi 3\% mampu menghasilkan gel yang stabil secara fisik. Nur Latifah Setyaningrum, ${ }^{17}$ melakukan penelitian serupa menggunakan basis HPMC dengan variasi konsentrasi $(3 \%, 3,5 \%$ dan $4 \%)$ menyebutkan basis HPMC 3,5\% merupakan basis gel yang memberikan penurunan keparahan lesi jerawat lebih baik dengan kontrol positif sebagai perbandingannya ${ }^{12}$. Aktivitas antibakteri ekstrak etanol dari daun senduduk pada konsentrasi 40 $\mathrm{mg} / \mathrm{ml}$ dengan metode agar difusi mempunyai diameter daya hambat terhadap pertumbuhan bakteri Staphylococcus aureus 10,40 $\mathrm{mm}^{15}$. Dan dari penelitian Liana ${ }^{8}$, ekstrak metanol daun senduduk memiliki daya aktivitas antibakteri teraktif dari Staphylococcus aureus di konsentrasi $200 \mathrm{mg} / \mathrm{ml}$ dan memiliki daya hambat 10,60 mm. Sedangkan penelitian Kusumowati ${ }^{16}$, Ekstrak etanol dari daun Senggani mempunyai KHM terhadap Staphylococcus aureus di konsentrasi $2 \%$.

Berdasarkan hal tersebut di atas menunjukkan bahwa ekstrak etanol dari daun senduduk memiliki daya aktivitas antibakteri, dan perlu dibuat formulasi sediaan farmasi. Produk gel antibakteri ekstrak etanol dari daun senduduk belum banyak ditemukan dipasaran, oleh karena itu akan dilakukan suatu penelitian dengan menggunakan ekstrak etanol dari daun senduduk untuk mengurangi efek samping yang berbahaya seperti pada penggunaan obat sintetik, yang diformulasikan dalam bentuk sediaan gel, dengan mempergunakan suatu basis gel HPMC, untuk secara topikal.

\section{METODE}

Metode Penelitian ini merupakan metode penelitian eksperimental dengan memformulasi Sediaan Gel Ekstrak Etanol Daun Senduduk (Melastoma malabathricum L.) Dengan Variasi Konsentrasi HPMC Sebagai Gelling Agent Terhadap Uji Kestabilan Fisik dan Antibakteri Pada Staphylococcus Aureus. Rancangan Penelitian dalam pengujian aktifitas sediaan adalah dengan pendekatan randomize post test- only control group design.

Objek penelitian menggunakan ekstrak etanol dari daun senduduk (Melastoma malabathricum L.) yang diperoleh dari simplisia daun senduduk (Melastoma malabathricum L.) secara metode maserasi. Daun senduduk (Melastoma malabathricum L.) yang digunakan diperoleh dari daerah talang kelapa Palembang. Penelitian dilakukan pada Oktober Desember 2017 bertempat di laboratorium farmakognosi, farmasetika, fisika farmasi Poltekkes Kemenkes Palembang Jurusan Farmasi dan Balai Besar Laboratorium Kesehatan Palembang.

Dengan metode eksperimental dengan membuat 3 jenis formula gel yang mengandung ekstrak etanol daun senduduk (Melastoma malabathricum L.) $4 \%$ dengan memvariasikan HPMC sebagai gelling agent pada konsentrasi 3\%, 3,5\% dan 4\%. Uji aktivitas antibakteri dilakukan dengan metode difusi agar terhadap bakteri Staphylococcus aureus. Sediaan disimpan selama 28 hari dan dievaluasi $\mathrm{pH}$, viskositas, homogenitas, intensitas warna dan bau serta iritasi kulit pada hari ke-0, ke-7, ke-14, ke-21 dan ke-28.

Pengumpulan data untuk formulasi Gel Ekstrak etanol daun senduduk (Melastoma malabathricum) dilakukan dengan cara melakukan pengamatan dan pengukuran secara langsung terhadap $\mathrm{pH}$, viskositas, daya sebar dan homogenitas yang dihasilkan dari sediaan gel selama 28 hari penyimpanan, sedangkan untuk pengamatan terhadap warna, bau, dan iritasi kulit sediaan gel dilakukan dengan menggunakan 30 orang responden, data yang didapat direkapitulasi dengan cara deskriptif analitik di laboratorium Farmakognosi, Fisika, dan Farmasetika di Politeknik Kesehatan Sedangkan untuk uji aktivitas antibakteri cara pengolahan dan analisis datanya yaitu dengan analisa statistika One Way ANOVA dengan mengukur diameter zona hambat bakteri Staphylococcus aureus yang dibandingkan dengan hasil kontrol positif dan hasil kontrol negative. 


\section{Tabel 1. Formula Sediaan Gel Ekstrak Etanol daun senduduk (Melastoma malabathricum L.)}

\begin{tabular}{|c|c|c|c|c|c|c|c|c|}
\hline \multirow{2}{*}{ No. } & \multirow{2}{*}{ Nama bahan } & \multicolumn{6}{|c|}{ Konsentrasi penggunaan (\%) } & \multirow{2}{*}{ Keterangan } \\
\hline & & F I & F II & F III & KI & K II & K III & \\
\hline & $\begin{array}{lcr}\text { ekstrak } & \text { etanol daun } \\
\text { senduduk } & \text { (Melastoma } \\
\text { malabathricum } & \text { L.) }\end{array}$ & 4 & 4 & 4 & - & - & - & Zat aktif \\
\hline 2. & HPMC & 3 & 3,5 & 4 & 3 & 3,5 & 4 & Gelling agent \\
\hline 3. & Propilen glikol & 15 & 15 & 15 & 15 & 15 & 15 & Humektan \\
\hline 4. & Metil paraben & 0,075 & 0,075 & 0,075 & 0,075 & 0,075 & 0,075 & Pengawet \\
\hline 5. & Propil paraben & 0,025 & 0,025 & 0,025 & 0,025 & 0,025 & 0,025 & Pengawet \\
\hline 6. & Dapar fosfat $\mathrm{pH} 6$ & ad 100 & ad 100 & ad 100 & ad 100 & ad 100 & ad 100 & $\begin{array}{l}\text { Pendapar dan } \\
\text { Pembawa }\end{array}$ \\
\hline
\end{tabular}

Sumber: Arikumalasari, Dewantara dan Wijayanti (2013), Suardi et al., (2008)

\section{HASIL}

Hasil Uji Kestabilan Fisik Sediaan Gel dari Ekstrak Daun Senduduk (Melastoma malabathricum L.).

\section{Stabilitas pH}

Tabel 2. Hasil Pemeriksaan pH Sediaan Gel Ekstrak Daun Senduduk (Melastoma malabathricum L.) Selama Penyimpanan 28 hari

\begin{tabular}{ccccccc}
\hline \multirow{2}{*}{ Gel } & \multicolumn{5}{c}{ Kestabilan Fisik pH } & \multirow{2}{*}{ Keterangan } \\
\cline { 2 - 5 } & 0 & 7 & 14 & 21 & 28 & \\
\hline Kontrol I & 5,59 & 5,55 & 5,50 & 5,23 & 5,18 & Memenuhi Syarat \\
Kontrol II & 5,27 & 5,25 & 5,25 & 5,10 & 5,15 & Memenuhi Syarat \\
Kontrol III & 5,25 & 5,22 & 5,19 & 5,12 & 5,10 & Memenuhi Syarat \\
Formula I & 5,46 & 5,44 & 5,40 & 5,45 & 5,42 & Memenuhi Syarat \\
Formula II & 5,25 & 5,27 & 5,19 & 5,08 & 5,02 & Memenuhi Syarat \\
Formula III & 5,10 & 5,10 & 4,95 & 4,80 & 4,70 & Memenuhi Syarat \\
\hline pH yang memenuhi syarat yaitu 4,5 -6,5 (sumber Tranggono dan Latifah 2007)
\end{tabular}

\section{Viskositas}

Tabel 3. Hasil Pemeriksaan Viskositas Sediaan Gel Ekstrak Daun Senduduk (Melastoma malabathricum L.) Selama Penyimpanan 28 hari

\begin{tabular}{ccccccc}
\hline \multirow{2}{*}{ Gel } & \multicolumn{5}{c}{ Kestabilan Fisik Viskosita; } & Keterangan \\
& 0 & 7 & 14 & 21 & 28 & \\
\hline Kontrol I & 22541 & 23055 & 23521 & 23627 & 24142 & Memenuhi Syarat \\
Kontrol II & 32381 & 32401 & 32861 & 33390 & 33558 & Memenuhi Syarat \\
Kontrol III & 40833 & 41453 & 41781 & 42079 & 42683 & Memenuhi Syarat \\
Formula I & 13971 & 14024 & 14630 & 14741 & 14830 & Memenuhi Syarat \\
Formula II & 29375 & 29972 & 30354 & 30384 & 30929 & Memenuhi Syarat \\
Formula III & 38420 & 40173 & 40245 & 40638 & 41023 & Memenuhi Syarat \\
\hline \multicolumn{7}{c}{ Viskositas yang memenuhi syarat 6.000-50.000 Centipoise (cp) } \\
\hline \multicolumn{7}{c}{ (SNI 16-4399-1996) } \\
\hline
\end{tabular}




\section{Daya Sebar}

Tabel 4. Hasil Pemeriksaan Daya Sebar Sediaan Gel Ekstrak Daun Senduduk (Melastoma malabathricum L.) Selama Penyimpanan 28 hari

\begin{tabular}{|c|c|c|c|c|c|c|}
\hline \multirow{3}{*}{ Gel } & \multicolumn{5}{|c|}{ Kestabilan Fisik Daya Sebar } & \multirow{3}{*}{ Keterangan } \\
\hline & \multicolumn{5}{|c|}{ Hari Ke- } & \\
\hline & $\mathbf{0}$ & 7 & 14 & 21 & 28 & \\
\hline Kontrol I & 5,4 & 5,4 & 5,2 & 5,2 & 5,0 & Memenuhi Syarat \\
\hline Kontrol II & 4,5 & 4,4 & 4,4 & 4,2 & 4,1 & Tidak Memenuhi Syarat \\
\hline Kontrol III & 4,3 & 4,2 & 4,1 & 4,1 & 4,0 & Tidak Memenuhi Syarat \\
\hline Formula I & 5,5 & 5,5 & 5,3 & 5,3 & 5,0 & Memenuhi Syarat \\
\hline Formula II & 5,3 & 5,3 & 5,3 & 5,1 & 4,9 & Memenuhi Syarat \\
\hline Formula III & 4,9 & 4,6 & 4,5 & 4,3 & 4,1 & Tidak Memenuhi Syarat \\
\hline Day & & & & & 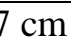 & rg et al, 2002) \\
\hline
\end{tabular}

\section{Homogenitas}

Tabel 5. Hasil Pemeriksaan Homogenitas Sediaan Gel Ekstrak Daun Senduduk (Melastoma malabathricum L.) Selama Penyimpanan 28 hari

\begin{tabular}{ccccccc}
\hline \multirow{2}{*}{ Gel } & \multicolumn{5}{c}{ Kestabilan Fisik Homogenitas } & \multirow{2}{*}{ Keterangan } \\
\cline { 2 - 4 } & $\mathbf{0}$ & $\mathbf{7}$ & $\mathbf{1 4}$ & $\mathbf{2 1}$ & $\mathbf{2 8}$ & \\
\hline Kontrol I & Homogen & Homogen & Homogen & Homogen & Homogen & Memenuhi Syarat \\
Kontrol II & Homogen & Homogen & Homogen & Homogen & Homogen & Memenuhi Syarat \\
Kontrol III & Homogen & Homogen & Homogen & Homogen & Homogen & Memenuhi Syarat \\
Formula I & Homogen & Homogen & Homogen & Homogen & Homogen & Memenuhi Syarat \\
Formula II & Homogen & Homogen & Homogen & Homogen & Homogen & Memenuhi Syarat \\
Formula III & Homogen & Homogen & Homogen & Homogen & Homogen & Memenuhi Syarat \\
\hline \multicolumn{7}{c}{ Homogenitas memenuhi syarat apabila distribusi partikel gel merata } \\
\hline \multicolumn{7}{c}{}
\end{tabular}

\section{Warna, Bau dan Iritasi Kulit}

Tabel 6. Hasil Pengamatan Warna , Bau dan uji Iritasi Kulit Sediaan Gel Ekstrak Daun Senduduk (Melastoma malabathricum L.) Selama Penyimpanan 28 hari

\begin{tabular}{|c|c|c|c|c|c|c|}
\hline \multirow[t]{2}{*}{ Gel } & \multicolumn{2}{|c|}{ Warna } & \multicolumn{2}{|c|}{ Bau } & \multicolumn{2}{|c|}{ Iritasi Kulit } \\
\hline & Berubah & $\begin{array}{c}\text { Tidak } \\
\text { Berubah }\end{array}$ & Berubah & $\begin{array}{c}\text { Tidak } \\
\text { Berubah }\end{array}$ & Iritasi & $\begin{array}{l}\text { Tidak } \\
\text { Iritasi }\end{array}$ \\
\hline Kontrol I & 0 & 30 & 0 & 30 & 0 & 30 \\
\hline Kontrol II & 0 & 30 & 0 & 30 & 0 & 30 \\
\hline Kontrol III & 0 & 30 & 0 & 30 & 0 & 30 \\
\hline Formula I & 0 & 30 & 0 & 30 & 0 & 30 \\
\hline Formula II & 2 & 28 & 0 & 30 & 0 & 30 \\
\hline Formula III & 1 & 29 & 2 & 28 & 0 & 30 \\
\hline
\end{tabular}

Keterangan: Diujikan Pada 30 responden. 
(JPP) Jurnal Kesehatan Poltekkes Palembang

Vol. 15, No. 2, Desember 2020, eISSN 2654-3427

DOI: $10.36086 /$ jpp.v15i2.557

\section{Aktivitas antibakteri}

Tabel 7. Hasil Pengukuran Diameter Daerah Hambatan Pertumbuhan kuman Staphylococcus aureus pada Sediaan Gel yang Mengandung Ekstrak Daun Senduduk (Melastoma malabathricum L.) Selama Penyimpanan 28 hari

\begin{tabular}{cccccc}
\hline & \multicolumn{5}{c}{ Aktivitas Antibakteri (mm) } \\
\cline { 2 - 6 } Gel & \multicolumn{5}{c}{ Hari Ke- } \\
\hline & 0 & 7 & 14 & 21 & 28 \\
Kontrol I & 0 & 0 & 0 & 0 & 0 \\
Kontrol II & 0 & 0 & 0 & 0 & 0 \\
Kontrol III & 0 & 0 & 0 & 0 & 0 \\
Formula I & 11,5 & 13,5 & 13,5 & 16,5 & 11 \\
Formula II & 16 & 14,5 & 15 & 13,5 & 10 \\
Formula III & 11 & 12,5 & 14,5 & 13 & 10 \\
\hline
\end{tabular}

Daya hambat:

Ekstrak Kental : I. $18 \mathrm{~mm}$

II. $18 \mathrm{~mm}$
Kontrol: Negatif HPMC $=0 \mathrm{~mm}$

Positif Ampicillin $=24 \mathrm{~mm}$

\section{PEMBAHASAN}

\section{Hasil Ekstraksi Daun Senduduk}

Penelitian ini menggunakan Daun Senduduk sebanyak $15 \mathrm{~kg}$ yang dikeringkan selama 5 hari tanpa terkena sinar matahari langsung agar senyawasenyawa kimia yang terkandung dalam daun senduduk tidak rusak, selain itu proses pengeringan juga bertujuan untuk menghilangkan kadar air dan mencegah pertumbuhan kapang. Hasil Daun senduduk yang telah dikeringkan diperoleh seberat $1,8 \mathrm{~kg}$. Daun senduduk kering kemudian diserbuk kasar untuk memperbesar luas permukaan simplisia sehingga cairan penyari lebih mudah masuk ke dalam sel-sel untuk kemudian terjadi perpindahan zat aktif dari dalam sel ke cairan penyari. Cairan penyari yang digunakan adalah etanol PA 96\% karena alkaloid, flavonoid dan tanin yang terkandung di dalam daun senduduk bersifat polar. Proses ekstraksi daun senduduk adalah menggunakan cara maserasi selama 5 hari. Ekstraksi dilakukan secara maserasi karena merupakan cara ekstraksi yang hanya menggunakan peralatan yang sederhana serta maserasi merupakan cara ekstraksi dingin yang digunakan untuk mencegah rusaknya zat aktif akibat pemanasan. Perlakuan selanjutnya dilakukan pengupan pelarut dengan menggunakan rotary evaporator dan didapatkan ekstrak kental daun senduduk sebanyak 181,23 gram dengan rendemen sebesar $10,07 \%$. Rendemen yang didapatkan pada penelitian ini berbeda dengan penelitian Sihombing (2014) yang mendapatkan hasil rendemen lebih tinggi yaitu sebesar 12,02\% dimana bila lebih tinggi rendemen yang didapatkan maka lebih banyak zat aktif yang tersari ${ }^{4}$. Perbedaan rendemen ini dapat disebabkan oleh perbedaan keadaan simplisia yang dimaserasi. Pada penelitian Sihombing (2014) simplisia yang digunakan adalah serbuk halus yang kemudian dimaserasi ${ }^{4}$ sedangkan pada penelitian ini digunakan adalah serbuk kasar. Menurut Ansel (2008) keadaan simplisia mempengaruhi rendemen, semakin halus simplisia maka nilai rendemen akan semakin besar ${ }^{9}$.

\section{Kestabilan Fisik Gel}

Setelah didapatkan ekstrak maka dilakukan pembuatan sediaan gel yang mengandung ekstrak daun senduduk. Kemudian dilakukan evaluasi selama 28 hari. Berdasarkan hasil pengamatan terhadap uji kestabilan fisik gel yang mengandung ekstrak daun senduduk yang meliputi $\mathrm{pH}$, Viskositas, Homogenitas, daya sebar, warna, bau dan iritasi kulit didapatkan hasil sebagai berikut:

\section{pH}

Pengukuran $\mathrm{pH}$ bertujuan untuk melihat apakah sediaan sesuai dengan $\mathrm{pH}$ kulit. $\mathrm{pH}$ pada setiap formula kontrol dan formula ekstrak menyebabkan perubahan $\mathrm{pH}$ sediaan gel, baik pada formula kontrol maupun formula ekstrak yaitu bekisar antara $\mathrm{pH}$ 4,70 - 5,59 dapat dilihat pada Tabel 2. pH ekstrak kental daun senduduk sendiri adalah 5 .

Derajat keasaman atau $\mathrm{pH}$ merupakan parameter penting dalam produk kosmetika karena 
bila $\mathrm{pH}$ sangat tinggi dapat menyebabkan kulit bersisik dan apabila $\mathrm{pH}$ terlalu rendah dapat membuat kulit teriritasi ${ }^{17}$. Idealnya $\mathrm{pH}$ sediaan topikal adalah sesuai dengan $\mathrm{pH}$ kulit yaitu 4,5$6,5{ }^{17}$ jadi $\mathrm{pH}$ yang dihasilkan pada penelitian ini memenuhi persyaratan baik $\mathrm{pH}$ pada formula kontrol dan $\mathrm{pH}$ pada Formula yang mengandung ekstrak daun senduduk. Estrak daun senduduk yang memiliki $\mathrm{pH} 5$ cenderung bersifar asam, agar $\mathrm{pH}$ setelah di buat sediaan gel tidak terlalu jauh berubah maka ditambahkan dapar fosfat $\mathrm{pH}$ 6 yang bertindak sebagai pemertahan $\mathrm{pH}$ sediaan yang diharapkan dapar fosfat bisa membuat $\mathrm{pH}$ sediaan menjadi stabil.

\section{Viskositas}

Pengujian viskositas bertujuan untuk menentukan nilai kekentalan dan konsistensi suatu zat. Berdasarkan hasil pengukuran viskositas gel ekstrak etanol daun senduduk selama 28 hari penyimpanan terlihat pada tabel 3 . Terjadi kecenderungan peningkatan viskositas selama 28 hari penyimpanan. Berdasarkan hasil viskositas yang diperoleh, viskositas tertinggi terdapat pada formula kontrol III dan Formula ekstrak III. Ini menunjukkan bahwa semakin tinggi konsentrasi HPMC yang digunakan maka viskositas sediaan gel akan semakin meningkat ${ }^{(18 ; 19)}$. Viskositas sediaan tidak bolah terlalu tinggi atau terlalu rendah, jika gel terlalu kental maka akan sulit dikeluarkan dan apabila terlalu encer maka tidak lama tinggal pada kulit saat digunakan. Viskositas sediaan berbanding terbalik dengan difusinya, viskositas yang rendah akan meningkatkan kecepatan difusi dalam pelepasan zat aktifnya sehingga makin tinggi konsentrasi gelling agent, makin besar viskositas sediaan maka makin kecil kecepatan pelepasan zat aktifnya ${ }^{20}$.

\section{Daya Sebar}

Daya sebar adalah karakteristik yang digunakan untuk memperhitungkan kemudahan saat digunakan, pengeluaran dari wadah dan mempengaruhi penerimaan konsumen ${ }^{21}$. Suatu sediaan yang baik dan lebih disukai bila dapat menyebar dengan mudah dikulit dan nyaman digunakan ${ }^{22}$. Pengujian daya sebar sediaan bertujuan untuk mengetahui seberapa baik sediaan gel menyebar di permukaan kulit, karena dapat mempengaruhi absorbsi obat dan kecepatan pelepasan zat aktif di tempat pemakaiannya (Setyaningrum, 2013). Parameter daya sebar yang baik yaitu berkisar 5-7 cm , bila diameter daya sebar kurang dari $5 \mathrm{~cm}$ maka gel tergolong dalam sediaan yang semi kaku (semistiff), namun bila diameter daya sebar antara 5-7 cm maka gel tergolong sediaan semi cair (semifluid) $^{21}$.

Hasil pengamatan daya sebar gel selama penyimpanan selama 28 hari didapatkan rentang diameter 4,1-5,5 $\mathrm{cm}$ dapat dilihat pada tabel 4 . Dimana terjadi penurunan daya sebar selama proses penyimpanan.

Penurunan daya sebar gel ekstrak etanol daun senduduk ini disebabkan oleh meningkatnya viskositas gel ekstrak daun senduduk. Hal ini juga berhubungan dengan variasi konsentrasi HPMC (gelling agent). Semakin tinggi konsentrasi HPMC yang digunakan maka viskositas akan semakin meningkat dan daya sebar akan menurun (Garg et $a l$, 2002). Daya sebar yang memenuhi persyaratan terdapat pada Formula kontrol I dengan rentang nilai daya sebar 5,0-5,4 cm, pada Formula ekstrak I rentng nilai daya sebar adalah $5,0-5,5 \mathrm{~cm}$ dan pda formula ekstrak II nilai daya sebar berkisar 4,9-5,3 cm. Nilai daya sebar yang tidak memenuhi syarat terdapat pada Formula Kontrol I dan II serta formula ekstrak III. Hal ini berkaitan dengan hasil viskositas yang didapat, karena pada umumnya daya sebar sediaan berbanding terbalik dengan viskositas, makin besar viskositas suatu sediaan, makin kental konsistensinya, maka makin kecil daya sebar yang dihasilkan ${ }^{21}$.

\section{Homogenitas}

Pengujian Homogenitas dilakukan untuk melihat distribusi atau sebaran partikel dalam sediaan gel selama 28 hari penyimpanan. Pengujian ini dilakukan melalui pengamatan secara langsung dibawah mikroskop pada pembesaran 100x, lalu diamati sebaran partikel setiap seminggu penyimpanan. Homogenitas pada sediaan gel dikatakan jika sediaan diletakkan pada kaca transparan tidak menunjukan adanya pengumpalan-pengumpalan dan adanya persamaan yang merata pada setiap formula ${ }^{23}$. Kemudian diamati secara langsung, ketika diraba dan digosokkan massa gel menunjukan susunan homogen serta tidak terasa adanya bahan padat pada kaca ${ }^{24}$. Pengamat selama penyimpanan 28 hari tidak menunjukan adanya partikel yang tidak homogen, semua partikel menyebar rata dan tidak ada pengumpalan partikel.

\section{Perubahan Bau dan Warna}

Pengujian perubahan bau dan warna dilakukan untuk mengetahui apakah sediaan gel ekstrak daun senduduk mengalami perubahan bau dan warna atau tidak selama penyimpanan 28 hari. Gel yang tidak stabil dapat ditandai dengan adanya perubahan fisik saperti bau dan warna ${ }^{25}$. 
Untuk pengamatan perubahan bau dan warna sediaan dibuat dalam skala kecil pada setiap minggunya. Pengamatan dilakukan oleh 30 orang responden yang sudah menandatangani persetujuan untuk ikut dalam evaluasi sediaan. Responden akan mencium dan mengamati warna dari sediaan gel dan kemudian akan mengisi kuisioner yang sudah disiapkan apakah ada perubahan bau dan warna setelah penyimpanan 28 hari.

Dari hasil yang didapatkan, sedian gel yang mengandung ekstrak daun senduduk memiliki bau khas daun senduduk dan warna sediaan gel yang mengandung daun senduduk memiliki warna hijau pucat karena pengaruh penambahan ekstrak daun senduduk sedangkan pada formula kontrol memiliki warna yang bening. Pada formula kontrol I, II dan III berdasarkan pengamatan responden tidak terjadi perubahan bau dan warna, sedangkan pada formula yang mengandung ekstrak daun senduduk Sebanyak 3 orang responden yang menyatakan perubahan warna yaitu 2 orang pada formula II dan 1 orang formula III. Sedangkan yang menyatakan perubahan bau pada formula kontrol III sebanyak 2 orang dapat dilihat pada tabel 6. Perubahan warna yang terjadi dapat disebabkan karena zat aktif pada ekstrak daun senduduk teroksidasi. Bau yang berubah pada sediaan dikarenakan pada pembuatan sediaan gel tidak ditambahkan corringen odoris sehingga bau khas dari daun senduduk tidak tertutupi.

\section{Uji Iritasi Kulit}

Pada penguji iritasi kulit dilakukan untuk melihat apakah ada reaksi alergi yang terjadi setelah sediaan dioleskan pada kulit seperti gatal, perih atau kemerahan. Uji iritasi kulit ini dilakukan terhadap 30 orang responden yang juga melakukan evaluasi bau dan warna diatas. Uji dilakukan pada punggung tangan responden kemudian ditunggu beberapa saat untuk melihat apakah ada reaksi alergi pada kulit. Pada hasil yang didapat dari 30 orang responden, $100 \%$ tidak mengalami gejala iritasi seperti kemerahan, rasa terbakar atau gatal pada kulit setelah penggunaan gel ekstrak daun senduduk. Hal ini menunjukan bahwa bahan-bahan dalam formula gel tidak menyebabkan iritasi pada kulit.

\section{Uji Aktivitas Antibakteri}

Uji Aktivitas antibakteri ini untuk mengetahui besarnya pelepasan zat aktif dengan mengukur diameter zona hambat pertumbuhan bakteri. Hasil uji aktivitas dari ekstrak daun senduduk pada formula kontrol I, II dan III serta
Kontrol negatif HPMC tidak memiliki zona hambat ini dikarenakan pada formula kontrol dan kontrol negatif tidak mengandung zat aktif yang dapat menghambat pertumbuhan bakteri Staphylococcus aureus. Sedangkan pada formula ekstrak terdapat zona hambat pertumbuhan bakteri Staphylococcus aureus. Pada ekstrak kental daun senduduk sendiri mempunyai zona hambat 18 mm. Pada formula ekstrak I zona hambat berkisar $11-16,5 \mathrm{~mm}$, formula II zona hambat berkisar 10 - $16 \mathrm{~mm}$ dan pada formula III zona hambat berkisar $10-14,5 \mathrm{~mm}$. Bila dilihat dari zona hambat pada formula ekstrak I, II dan III tidak jauh berbeda, kemungkian ini di karenakan konsentrasi kadar ekstrak pada tiap formula adalah sama sebesar $4 \%$. Ini tidak jauh berbeda pada penelitian sihombing (2014) ${ }^{15}$ zona hambat dari ekstrak daun senduduk $4 \%$ terhadap bakteri Staphylococcus aureus adalah 10,40 mm. Daerah zona hambat $10-20 \mathrm{~mm}$ termasuk kategori kuat ${ }^{26}$. Sebagai kontrol positif digunakan antibiotika Amoksisilin. Amoksisilin digunakan karena merupakan antibiotika spektrum luas, serta dapat larut dalam air ${ }^{27}$. Zona hambat dari Amoksisilin sebesar $24 \mathrm{~mm}$.

Untuk menguji apakah terjadi perubahan zona hambatan yang bermakna setelah penyimpanan 28 hari, dilakukan uji statistik oneway anova $(p<0,05)$ untuk membandingkan zona hambatan pada sediaan pada hari ke- 0 , ke- 7 , ke-14, ke-21 dan ke-28. Ternyata didaptkan signifikasinya $0,412 \quad(p>0.05)$. sehingga dapat disimpulkan bahwa tidak ada perubahan yang bermakna pada uji aktivitas antibakteri pada hari penyimpanan.

\section{KESIMPULAN DAN SARAN}

Formulasi dan Efektivitas Antibakteri Sediaan Gel Antiseptik Tangan Ekstrak Etanol Daun Senduduk (Melastoma malabathricum L.) Terhadap Staphylococcus Aureusdan Pseudomonas Aeruginosa" selama 28 hari penyimpanaan memenuhi persyaratan $\mathrm{pH}$, viskositas, daya sebar, homogenitas, warna, bau dan yang paling penting itu tidak mengiritasi kulit. Uji aktivitas antibakteri pada setiap formula gel yang mengandung ekstrak etanol Daun Senduduk (Melastoma malabathricum L.) memiliki daya hambat antibakteri terhadap bakteri Staphylococcus Aureus.

Formula yang direkomendasikan untuk dibuat sediaan adalah Formula Ekstrak I. Perlu dilakukan penlitian lebih lanjut uji dipercepat untuk mengetahui jangka waktu sediaan dapat bertahan. Penambahan zat corrigen odoris ke 
dalam formula gel Ekstrak Etanol Daun Senduduk (Melastoma malabathricum L.) untuk menutupi bau khas daun senduduk.

\section{UCAPAN TERIMA KASIH}

Penulis mengucapkan terima kasih kepada Direktur Poltekkes Kemenkes Palembang yang sudah memfasilitasi dana penelitian, serta pihak-pihak yang telah membantu pelaksanaan penelitian ini.

\section{DAFTAR PUSTAKA}

1. Mardiastuti, Karuniawati, A., Kiranasari, A., et al, 2007. Emerging Resistance Pathogen: Situasi Terkini di Asia, Eropa, Amerika Serikat, Timur Tengah dan Indonesia. Majalah Kedokteran Indonesia, 57 (3): 75-79.

2 Jawetz., et al. 2007. Mikrobiologi Kedokteran Jawetz, Melnick, \& Adelberg, Ed.23, Translation of Jawetz, Melnick, and Adelberg's Medical Microbiology, 23Th Ed. Alih bahasa oleh Hartanto, H., et al. Jakarta: EGC

3. Dinas Kesehatan Kota Palembang, 2012. 10 Penyakit Terbesar di Kota Palembang. Dinas Kesehatan Kota Palembang, Indonesia

4. Samsumaharto, R. A., \& Hartanto, S. D., 2010, Uji Akivitas Antibakteri Ekstrak nHeksan, Etil Asetat,dan Etanol $70 \%$ Daun Kembang Sepatu (Hibiscus rosasinesis L.) Terhadap S. aureus ATCC 25923, Laporan Penelitian: Universitas Setia Budi, Surakarta

5. Dalimartha, S. (2008). Atlas Tumbuhan Obat Indonesia Jilid 1. Jakarta: Perpustakaan Nasional RI, 130-132

6. Simanjuntak R.Megawati. (2008). Ekstrak Fraksinasi Komponen Ekstrak daun Tumbuhan Senduduk (Melastoma Malabatharicum,L) Serta Pengujian Efek Sediaan Krim Terhadap Penyembuhan Luka Bakar, Universitas Sumatera Utara, Medan.

7. Kusumowati dkk, 2014, Daya Antibakteri Ekstrak Etanol Daun Senggani (Melastoma affine D. Don) Fakultas Farmasi Universitas Muhammadiyah Surakarta

8. Liana ida, 2010. Aktivitas Antimikroba Fraksi dari Ekstrak Metanol Daun Sendudukm (Melastoma Malabathricum L) Terhadap Staphylococcus aureus dan
Salmonella typhimurium Serta Profil Kromatograi Lapis Tipis Fraksi Teraktif. Universitas Sebelas Maret, Surakarta.

9. Ansel, H.C, 2008. Pengantar Bentuk Sediaan Farmasi Edisi IV. Terjemahan Oleh: Ibrahim,F, Asmanizar dan Aisyah I. Universitas Indonesia Press. Jakarta, Indonesia

10. Lachman, L., H.A. Lieberman dan J.L. Kanig, 1994. Teori dan Praktek Farmasi Industri Edisi Ketiga. Terjemahan Oleh Siti Suyatmi, J. Kawira, Iis Aisyah. UI Press. Jakarta, hal 1092, 1095-1098, 1119

11. Madan, J., \& Singh, R., 2010, Formulation and Evaluation of Aloevera Topical Gels, Int.J.Ph.Sci., 2 (2), 551-555.

12 Nur Latifah Setyaningrum, 2013, pengaruh Variasi Kadar Basis HPMC dalam Sediaan Gel Ekstrak Etanolik Bunga Kembang Sepatu (Hibiscus rosa sinensis L.) terhadap sifat fisik dan Daya Antibakteri pada Staphylococcus aureus, Naskah Publikasi; Universitas Muhammadiyah Surakarta., 3.

13. Wade A. dan P.J. Weller. 1994. Handbook of Pharmaceutical Excipients Second Edition. American Pharmaceutical Association. Washington, New York

14. Arikumalasari, J, I.G.N.A. Dewantara, N.P.A.D. Wijayanti, 2013. Optimasi HPMC sebagai Gelling Agent dalam Formula Gel Ekstrak Kulit Buah Manggis (Garcinia mangostana L.). Jurnal Farmasi Udayana

15. Sihombing Yanna Rotua, 2014, Uji Aktivitas Antibakteri Ekstrak Etanol Daun Senduduk (Melastoma malabathricum L.) terhadap Bakteri Staphylococcus aureus, Staphylococcus epidermidis DAN Escherichia coli, USU, Medan

16. Kusumowati, Melannisa dan Prasetyawan, 2014, Daya Antibakteri Ekstrak Etanol Daun Senggani (Melastoma affine D. Don), Universitas Muhammadiyah, Surakarta.

17. Tranggono, R.I., Latifah, F. 2007. Buku Pegangan Ilmu Pengetahuan kosmetik. PT. Gramedia : Jakarta

18. Rowe, R.C., P.J. Sheskey dan M.E. Quinn, 2009. Handbook of Pharmaceutical Excipients Sixth Edition. American Pharmaceutical Association. London, Chicago

19. Faizatun, Kartiningsih, \& Liliyana, 2008, Formulasi Sediaan Shampo Ekstrak Bunga Chamomile dengan Hidroksi Propil Metil Selulosa sebagai Pengental, Jurnal Ilmu 
Kefarmasian Indonesia, 6 (1), 18-19.

20. Sukmawati, A. \& Suprapto, Efek Berbagai Peningkat Penetrasi Terhadap Penetrasi Perkutan Gel Natrium Diklofenak Secara In Vitro, Jurnal Penelitian Sains \& Teknologi, 11 (2), 117 - 12.

21. Garg, A., D. Anggarwal, S. Garg, dan A.K. Singla, 2002. Spreading of Semisolid Formulations. USA: Pharmaceutical Technology, hal. 84-104.

22 Wyatt, E. L., Sutter, S. H., \& Drake, L. A., 2008, Dermatology Pharmacology; In: Hardman, J. G., Limbird, L. E., \& Gilman, G. (eds.), Goodman \& Gilman's the Pharmacological Basis of Therapeutics, 10 th edition, 1763, McGraw-Hill, New York

23. Agral, O., Fatmawati,. Yamlean, P., Sri Supriati, H. 2013. Formulasi Uji Kelayakan Sediaan Krim Anti Inflamasi Getah Tanaman Patah Tulang (Euphorbia tirucalli L.) Pharmacon, Vol.2 No.03

24. Kurniawati, L., I. Hapsari, dan D. Hartanti,. 2010. Daya Repelan Gel Minyak
Atsiri Bunga Kenanga (Cananga odorata (Kmk) Hook.f \& Thoms) dalam Basis Carbopol terhadap nyamuk Aedes aegypti. Pharmacy. Vol.07, No.03: Purwokerto

25. Collet, D.M dan M.E. Aulton, 1990. Pharmaceutical Practice. Churchill Livingstone. New York, hal. 127-128

26. Davis, W.W. \& Stout, T.R., 1971. Disc plate method of microbiological antibiotic assay. II. Novel procedure offering improved accuracy. Applied microbiology, 22(4), pp.666670.(http://www.ncbi.nlm.nih.gov/pmc/artic les/ PMC376382/pdf/applmicro0012 0- 0197.pdf Diakses pada 5 april 2017).

27. Tjay, T.H. dan K. Rahardja. 2015. ObatObat Penting Khasiat, Penggunaan dan Efek-Efek Sampingnya Edisi VI. PT Elex Media Komputindo. Jakarta, Indonesia, hal. 61 